\title{
Morphoanatomical characterization and chemical study of the internal portion of the stem bark of Sambucus australis Cham. \& Schltdl
}

\author{
ALERICO, G.C. ${ }^{* *}$; VIGNOLI-SILVA, M.2; LANDO, V.R. ${ }^{2}$ \\ 'Universidade Federal do Rio Grande do Sul, Av. Ipiranga 2752, 90.610-000, Porto Alegre, RS, Brazil. \\ 2Universidade Federal de Ciência da Saúde de Porto Alegre, Av. Sarmento Leite 245, 90050-170, Porto Alegre, \\ RS, Brazil. *Autor para correspondência: gabrielaalerico@gmail.com
}

\begin{abstract}
Sambucus australis Cham. \& Schtdl. (Adoxaceae) is an arboreal species native to the south of Brazil, known as "sabugueiro". The internal part of the stem bark of this species is used to produce a homemade ointment in some regions of the state of Rio Grande do Sul. The purpose of this study is to characterize the morphoanatomy and identify the compounds present in the internal part of the stem bark of $S$. australis through chemical and histochemical methods. In addition, the best extraction conditions for the sample were determined. It was possible to quantify the rutin and total phenolic compounds, as well as define the Soxhlet method with an $80 \%$ hydroethanolic solution as the best method for extracting these compounds from the bark of the species. The portion of the stem bark that is popularly used could also be determined. Based on the results, new studies will be performed in order to identify other characteristics of the species and the possible reasons that sustain its traditional use.
\end{abstract}

Keywords: Sambucus australis, bark, cicatrization, traditional use.

RESUMO: Caracterização morfoanatômica e estudo químico da porção interna da casca do caule de Sambucus australis Cham. \& Schltdl. Sambucus australis Cham. \& Schtdl. (Adoxaceae) é uma espécie arbórea nativa do sul do Brazil, conhecida como "sabugueiro". A parte interna da casca do caule dessa espécie é utilizada na produção de uma pomada caseira em algumas regiões do estado do Rio Grande do Sul. O objetivo desse estudo é caracterizar a morfoanatomia e identificar compostos presentes na parte interna da casca do caule de $S$. australis por métodos químicos e histoquímicos. Ademais, realizou-se avaliações para determinar as melhores condições extrativas para a amostra. Foi possível quantificar rutina e compostos fenólicos totais, além de determinar o método Soxhlet com solvente hidroetanólico $80 \%$ como o melhor método para extrair esses compostos da casca da espécie. Ainda foi possível determinar a porção da casca do caule utilizada popularmente. Com base nos resultados, novas investigações serão realizadas a fim de determinar mais características da espécie e as possíveis razões que corroboram o uso tradicional.

Palavras-chave: Sambucus australis, casca, cicatrização, uso tradicional.

\section{INTRODUCTION}

Plants are widely used to medical purposes and have a significant role in the traditional health and in the development of drugs. Besides, more than $50 \%$ of all drugs available, derivate from natural products (Newman \& Cragg, 2012).

In this context, Sambucus L. genus, belonging to Adoxaceae family (Judd et al., 2009), is widely known by its species properties, for example, S. nigra L. had its immunomodulatory functions showed by Barsett et al. (2012). Other species include $S$. chinensis Lindl (Zhang et al.,
2010) and S. australis Cham \& Schltdl (Rao et al., 2011), from which were isolated a few flavonoids and ursolic acid respectively, whereas S. ebulus L. has anti-inflammatory activity (Ebrahimzadeh et al., 2006) and S. canadensis L. was pointed out by its antioxidant action (Ozgen et al., 2010).

Sambucus australis, popularly known in Brazil as "sabugueiro", and "sabugueiro-do-Brasil", has an arborescent habit and is a native species from Brazilian forest formations from Amazônia and Mata Atlântica. Its occurrence was registered in the 
North (Amazonas), Northeast (Rio Grande do Norte, Paraíba, Pernambuco and Bahia), Southeast (Minas Gerais and São Paulo) and South regions (Paraná, Santa Catarina e Rio Grande do Sul) from Brazil (Sobral, 2010). As a medicinal plant, S. australis has been used to treat several conditions, and is cited as one of Brazilian native species with current or potential economic value (Coradin et al., 2011).

There are few studies with $S$. australis leaves and flowers; Scopel et al. (2010) and Rao et al. (2011). The last showed, with his study, the preventive action of ursolic acid in the abdominal adipogenesis and its promising use as an antiobesity multiple-target agent. However, in Northern region from Rio Grande do Sul state, the internal portion of the $S$. australis stem bark is used too, by some people, in the production of a homemade ointment (Personal communication of the first author's grandfather). According to popular reports, the ointment, when applied over skin burns, shows analgesic and wound healing effects, the last described only to S. ebulus (Süntar et al., 2010). Also, S. australis appears in ethnobotanical surveys conducted in Rio Grande do Sul state, as a species used traditionally for wound-healing purposes (Somavilla \& Canto-Dorow, 1996; Barros et al., 2007; Vendruscolo, 2004). Besides, in one of these studies, the part used as remedy is the internal portion of the stem bark (Vendruscolo, 2004). It is important to highlight the need for new wound healing agents, considering the implications of a chronic wound for example. Chronic wounds are a burden on the health care system, whereas regarding the high costs attached or the loss of life quality of the patients (Sen et al. 2009).

Barks of other two Brazilian native species are use in Brazil by the herbal industry, one from Erythrina verna Vell.(Fabaceae), popularly known as "mulungu" and the other from Stryphnodendron adstringens (Mart.) Coville (Fabaceae), known as "barbatimão" (Farmacopeia Brasileira, 2000; Rambo et al., 2013). Macroscopically, the barks from the two species differ from each other in form, appearance, texture and color. Other exotic species barks utilized in Brazil to medicinal purpose are Cinnamomum cassia (L.) J. Presl (Lauraceae), Quillaja saponaria Mol. (Quillajaceae), Salix alba L. (Salicaceae) (Farmacopeia Brasileira, 2010), Cinchona pubescens Vahl (Rubiaceae), Cinnamomum verum J.S. Presl (Lauraceae) (Farmacopeia Brasileira, 2000) and Rhamnus purshiana DC. (Rhamnaceae) (Farmacopeia Brasileira, 1996). The comparison of the several barks is important for differentiating the material used to produce drugs. The purpose of this paper is to investigate the morphoanatomic and chemical characteristics of the stem bark's internal portion of
S. australis, material used to produce the homemade ointment, in Northern region from Rio Grande do Sul state, based on the ethnopharmacological relevance of the species.

\section{MATERIALS AND METHODS \\ Plant material}

The internal part of the stem bark of $S$. australis was collected in the municipality of Passo Fundo (28`15'58”S; 52²4'59”W), northern Rio Grande do Sul. The collection occurred in January 2013, the sample was identified and a voucher was deposited in the Herbarium (ICN) of Universidade Federal do Rio Grande do Sul (Voucher number: ICN 184327). The sample was dried at room temperature, hidden from sunlight, and powdered with a blender.

\section{Morphoanatomical and histochemical analysis}

For the identification of the bark tissue involved on the study, a horizontal slice of bark was collected and softened in a mixture of water, ethanol and glycerin (2:2:1) for ten days. Transversal and longitudinal histological sections were carried out with razor blades and observed in optical microscope.

Histochemical tests, referred in several studies (Rambo et al 2013; Brazilian Pharmacopoeia 2010. Nunes et al, 2007) and methodologies suggested by some authors (Leite 2009; Macêdo, 1997; Argüeso, 1986) were applied. With fresh material, the histochemical tests were performed for alkaloids with Dittmar reagent (Leite, 2009), for lignins with acidic phloroglucinol (Leite, 2009), starch grains with Lugol reactive (Leite, 2009), cellulose with toluidine blue (Macêdo, 1997), phenolic compounds with ferric chlorate (Leite, 2009), calcium oxalate crystals with sulfuric acid $50 \%$ (Macêdo, 1997), lipids with Sudan IV (Leite, 2009), saponins with concentrated sulfuric acid (Macêdo, 1997) and tannins with ferric chlorate $10 \%$ and sodium carbonate $2 \%$ (Argüeso, 1986).

\section{Chemical analysis}

The variables for the extraction conditions study were extraction method, temperature, time, solvent, sample mass and solvent volume. To compare the different extraction parameters, the quantification values of rutin and total phenolic content were used.

The sample was extracted by maceration, ultrasound-assisted, Soxhlet and reflux, each one with two different time extraction, being 30 and 60 minutes for the first two, and 60 and 240 minutes for the following. And, maceration was done under different temperature conditions, room temperature

Rev. Bras. PI. Med., Campinas, v.18, n.1, supl. I, p.223-229, 2016. 
$\left(25^{\circ} \mathrm{C}\right)$ and $60^{\circ} \mathrm{C}$. All extractions were performed using methanol, then the most promising one was evaluated with hidroethanolic solution $80 \%$ as solvent.

Rutin quantification was done by UV-VIS spectrophotometry, 356nm wavelength, using an analytical curve with rutin standard (Sigma-Aldrich). And total phenolic content was determined by FolinCiocalteau method according to Fazio et al. (2013), the results are showed as milligrams of gallic acid equivalent (GAE) per gram of dried sample (GAE/g).

\section{Statistical analysis}

Results are presented as mean \pm standard deviation. Data was submitted to variance analysis (Anova) and Tukey Test, and analyzed with software Minitab 1.6. Results were considered significate different if $p<0.05$.

\section{RESULTS AND DISCUSSION Morphoanatomic and organoleptics characteristics}

In a transversal section, the stem is macroscopical characterized by the dark colored peridermis, followed by a thin cream or pale yellow colored layer of phloem, with fibrous aspect and characteristic odor. In sequence, the organ presents a layer of xylem, well developed, with a lighter color than the other tissues, followed by a fistulous medulla. Stem bark is known as all the tissues located externally to the vascular cambium of this organ (Metcalfe \& Chalk, 1979). However, the target of this study is only the internal portion of the stem bark, correspond to the phloem. Some stem barks, used as vegetal drugs as Cinnamomum cassia (L.) J. Presl e Stryphnodendron adstringens, are constituted by peridermis and phloem (Farmacopéia Brasileira, 2010), while others, as Cinnamomum verum e Quillaja saponaria Mol. are only constituted by peridermis. The internal portion of the stem bark of $S$. australis presents some similarities with Q. saponaria, especially regarding the flat shape, smooth texture and pale yellow color, according to the macroscopical description of the drug, presented on the Brazilian Pharmacopoeia (2010) for the last species. However, the phloem fibers characteristics can help in the differentiation of both species. In $S$. australis the fibers are angle, with thick walls and small lumen, and do not present the tortuous aspect, as described for $Q$. saponaria fibers (Farmacopeia Brasileira, 2010).

\section{Microscopical characteristics}

In transversal section, the phloem presents continuous distribution. The tissue is composed by axial parenchyma cells, sieve tube elements, companion cells and sclerenchyma fibers. Still composing the phloem, there are radial parenchyma cells, which form cell rays, sometimes more elongated than the axial (Figure 1).

The fibers are angle, with thick walls and small lumen; they are arranged in tangential groups, alternately distributed with little and few evident groups of conductive cells (sieve tube elements and companion cells) and well developed layers of axial parenchyma cells. Intercalated to these layers, there are the well-defined parenchyma rays, formed by well-organized parenchyma cells (Figure 1).

The fibers exhibit simple pits. Conductor cells are fewer than fibers and parenchyma cells, which have several shapes and sizes. In the parenchyma cells interior are alkaloids, calcium oxalate prismatic crystals, lipid drops and a large amount of starch grains. These cellular constituents react positively to histochemical tests with Dittmar reagent, sulfuric acid, Sudan IV and Lugol reactive, respectively (Figures 2 and 3). Nunes et al. (2007) report the absence of idioblasts with calcium oxalate sandy crystals in the $S$. australis flowers' tissues, neither have they mentioned the presence of other calcium oxalate sandy crystal forms. Large amounts of lipid drops (volatile and non volatile oil globules) and starch grains were found in the $S$. australis flowers analysis (Nunes et al., 2007).

The result for alkaloids was evident when the histochemical test was applied in fresh material. Besides the evidence of alkaloids in the interior of parenchyma cells, the fibers walls were also colored, indicating a positive result with Dittmar reagent. However, alkaloids are not molecules commonly

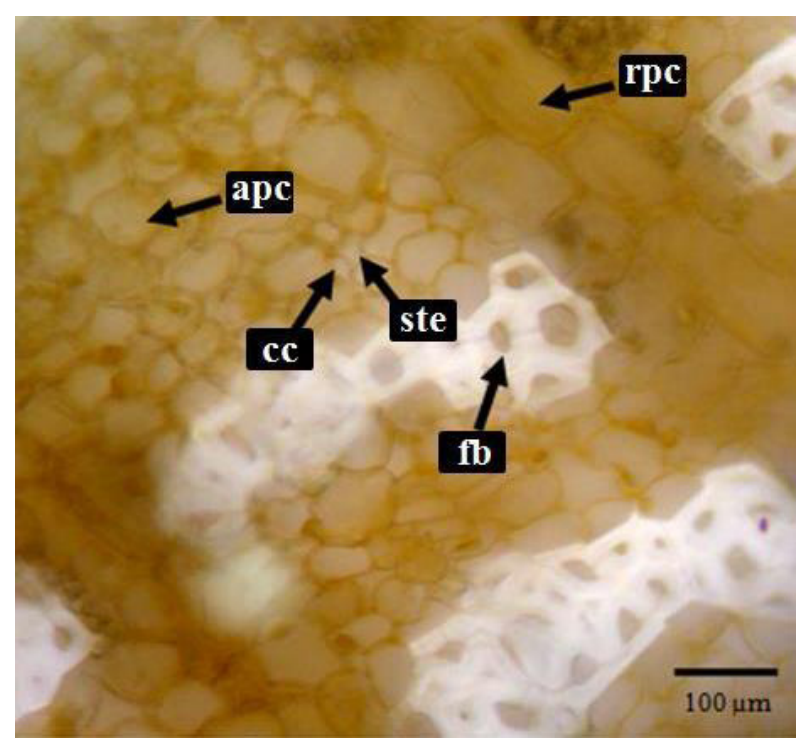

FIGURE 1. Sambucus australis Cham. \& Schltdl. Phloem in transversal section. cc: companion cells; apc: axial parenchyma cell; rpc: radial parenchyma cell; ste: sieve tube element; fb: fiber. (Fresh material, no dye). 
found in cell wall constitution. Also, it was observed positivity for the cellulose and lignin tests. The presence of these metabolites makes the species interesting from the chemical view and can stimulate further studies.

Regarding the histochemical tests applied to detect specifically phenolic compounds, saponins and tannins, the results were negative, in agreement with the results found by Alice et al. (1991). The author also described the absence of alkaloids on the flowers, but found positivity for flavonoids and terpenoids/steroids (Alice et al., 1991). However, total phenolic compounds were detected in the extract analysis (as will be presented later), which agrees to the results found by Alice et al. (1991), regarding the flavonoids. Nunes et al. (2007) did not applied histochemical tests for phenolic compounds, saponins and tannins, so there is no report $f$ the presence of these compounds on $S$. australis flowers.

In tangencial longitudinal view, axial parenchyma cells show a more elongated aspect when compared to the radial parenchyma cells, being the characteristics cited above for the conductor cells and fibers, also evidenced here (Figure 4).

\section{Chemical study}

The success of bioactive compounds extraction depends on many factors such as plant material, solvent, temperature, pressure and time (Azmir et al., 2013), in this study, some of this factors were evaluated in order to optimize the extraction process of the stem bark of $S$. australis. In Table 1

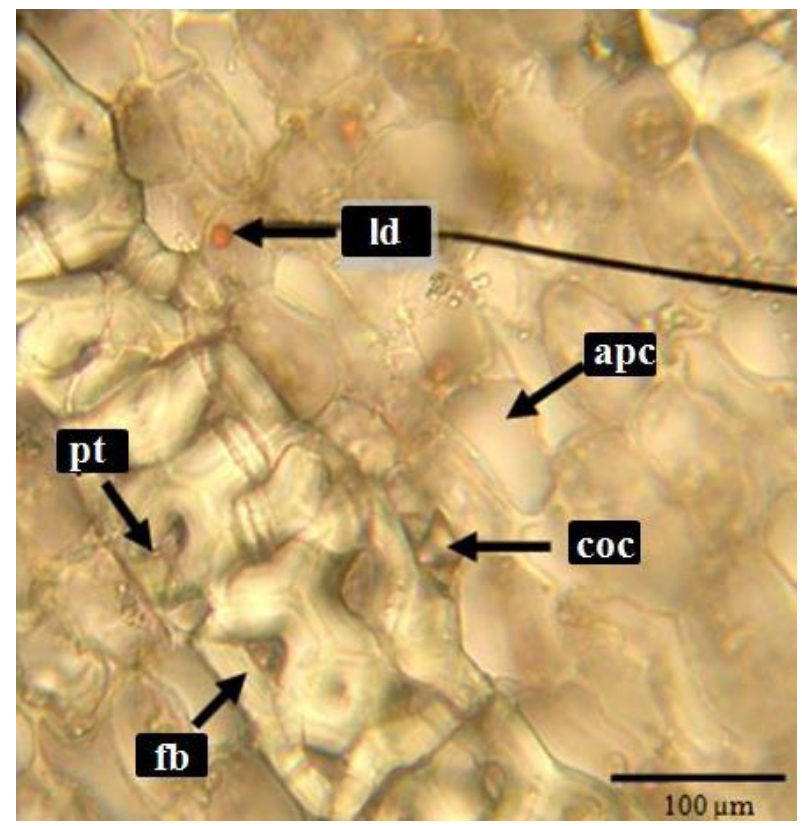

FIGURE 2. Sambucus australis Cham. \& Schltdl. Phloem in transversal section. coc: calcium oxalate crystal; apc: axial parenchyma cell; fb: fiber; Id: lipid droplet; pt: pits. (Stained with Sudan IV).

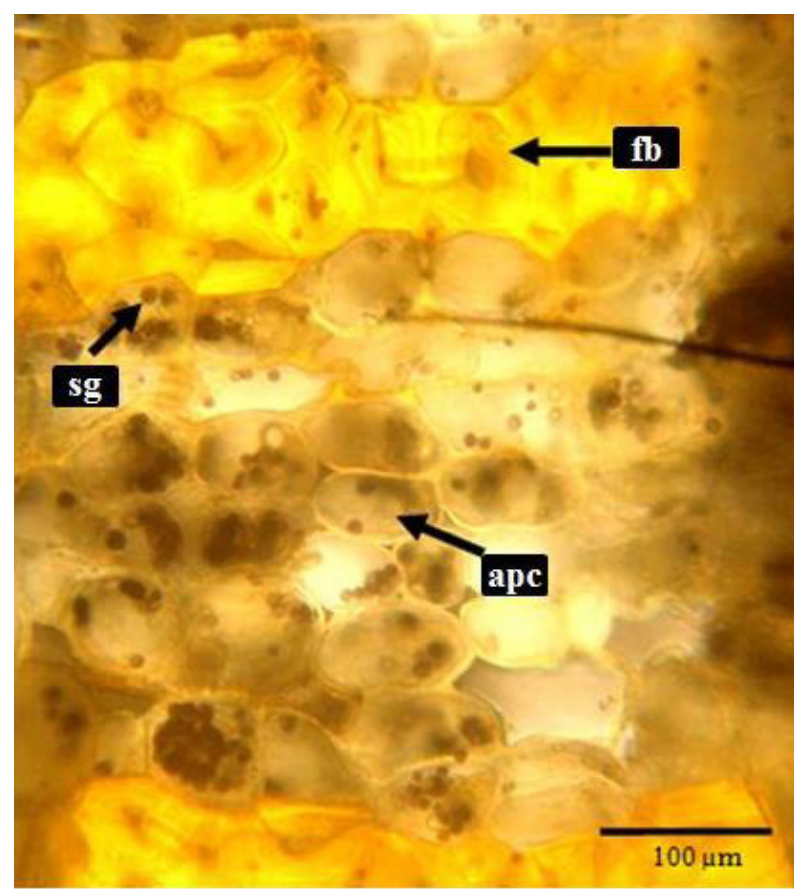

FIGURE 3. Sambucus australis Cham. \& Schltdl. Phloem in transversal section. apc: axial parenchyma cell; fb: fiber; sg: strach grain. (Stained with lugol).

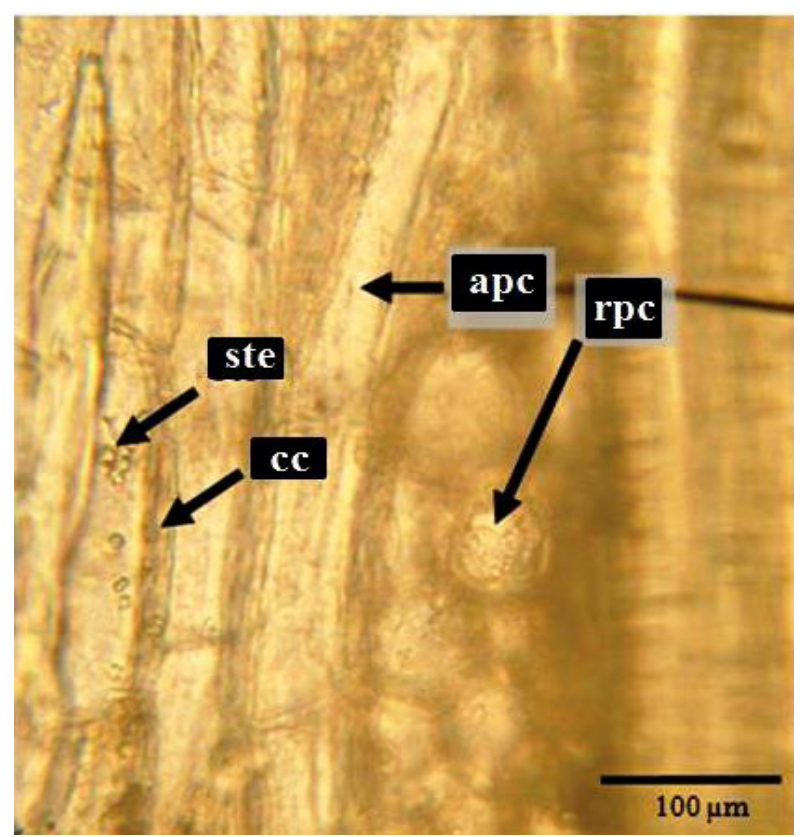

FIGURE 4. Sambucus australis Cham. \& Schltdl. Phloem in transversal section. cc: companion cells; apc: axial parenchyma cell; rpc: radial parenchyma cell; ste: sieve tube element. (Fresh material, no dye).

are presented the quantification results of rutin and total phenolic compounds.

The extraction method that presented the best results was Soxhlet, followed by reflux, ultrasound-assisted and maceration. This information 
TABLE 1. Results for different extraction methods.

\begin{tabular}{lccc}
\hline Extraction Method & Time (minutes) & Rutin $(\mathbf{m g} / \mathbf{g})$ & Total Phenolic Compounds $(\mathbf{m g}$ GAE/g) \\
Hot Maceration & 30 & $0.72 \pm 0.10^{\mathrm{b}}$ & $45.02 \pm 5.25^{\mathrm{bcd}}$ \\
Maceration & 60 & $0.63 \pm 0.05^{\mathrm{b}}$ & $49.81 \pm 6.01^{\text {bod }}$ \\
& 30 & $0.26 \pm 0.04^{\circ}$ & $25.49 \pm 10.07^{\mathrm{d}}$ \\
Ultrasound-assisted & 60 & $0.27 \pm 0.01^{\circ}$ & $26.16 \pm 12.47^{\mathrm{d}}$ \\
& 30 & $0.81 \pm 0.04^{\mathrm{b}}$ & $64.57 \pm 1.50^{\mathrm{ab}}$ \\
Soxhlet & 60 & $0.66 \pm 0.09^{\mathrm{b}}$ & $52.32 \pm 9.39^{\mathrm{bc}}$ \\
\multirow{2}{*}{ Reflux } & 60 & $0.29 \pm 0.12^{\mathrm{c}}$ & $27.08 \pm 6.16^{\mathrm{cd}}$ \\
& 240 & $1.05 \pm 0.01^{\mathrm{a}}$ & $81.54 \pm 12.59^{\mathrm{a}}$ \\
& 60 & $0.70 \pm 0.11^{\mathrm{b}}$ & $44.82 \pm 10.56^{\mathrm{bcd}}$ \\
\hline
\end{tabular}

Values that don't share a letter are statistically different $(p<0.05)$.

is consistent with the consulted literature, in which the Soxhlet method presented better results than maceration (Scalia et al., 1999) and ultrasoundassisted extraction (Péres et al., 2006). These findings may be due the fact that in Soxhlet extraction, the sample remains continuously in contact with the extractor solvent, and also due the ability of the system to retain high temperatures. Furthermore, is a simple technique and has no need of filtration after the process. However, there are some disadvantages, as the large amount of solvent needed and the fact that the system provides no agitation (Carvalho et al., 2009; Luque de Castro \& Priego-Capote, 2010).

Except for the Soxhlet method, the time of extraction was not a key factor in this study. On the contrary, the literature points the variable time as important for the quality of extractions, Lapornik et al. (2005) compared time extractions of 1, 12 and 24 hours, and demonstrated that longer time extractions can provide 6-7 times higher values of polyphenols. This supports the Soxhlet results, once this technique demands longer extractions, differently from maceration and ultrasound-assisted extraction. Also, Hamissa et al. (2012) found that the extraction time is important in the extraction of total phenolic compounds and total flavonoids.

Extraction temperature was found statistically relevant for the extraction of rutin and polyphenols. The comparison between maceration at $25^{\circ} \mathrm{C}$ and at $60^{\circ} \mathrm{C}$ provided similar results to the literature, which demonstrate that high temperatures improve the extraction of polyphenols (Leite, 2009; Hamissa et al., 2012).
It was possible to determine that the extraction solvent plays an important role in the process, once the solvent must extract the wanted compounds from the plant material. Methanol, ethanol and their combinations are commonly used for the extraction of phenolics from plant materials (Dai \& Mumper, 2010). Table 2 present the quantification results of rutin and polyphenols for methanol and ethanol $80 \%$.

In this study, the most polar solvent, ethanolic solution $80 \%$, showed the best results for the analyzed compounds. This result is supported by Shi et al. (2005) and Chua (2013), who considered alcoholic mixtures the best choice for extraction of polyphenols. Also, ethanol is preferred because is a non-toxic solvent.

The presence of high quantities of phenolic compounds in the sample evaluated may support the traditional of this plant, once this class of chemical compounds is known to stimulate the proliferation of skin cells, helping wound-healing (Ratz-Łyko et al., 2015).

\section{CONCLUSION}

The results allowed demonstrating the importance of optimized extraction conditions and an appropriate solvent to the interest molecules. Since a four hours Soxhlet extraction, using ethanol $80 \%$ as solvent was considered the most efficient for rutin and polyphenols from the inner stem bark of $S$. australis. Also, the botanical analysis allowed determining the portion used as remedy as the phloem, as well as detected metabolites in situ.

TABLE 2. Results of rutin and phenolic compounds for different solvents.

\begin{tabular}{ccc}
\hline Extraction Solvent & Rutin $(\mathbf{m g} / \mathbf{g})$ & Phenolic Compounds $(\mathbf{m g}$ GAE/g) \\
\hline Methanol & $1.05 \pm 0.01^{\mathrm{b}}$ & $81.55 \pm 12.60^{\mathrm{b}}$ \\
Ethanol $80 \%$ & $1.61 \pm 0.10^{\mathrm{a}}$ & $137.79 \pm 26.31^{\mathrm{a}}$ \\
\hline
\end{tabular}

Values that don't share a letter are statistically different $(p<0.05)$. 
The macroscopical aspect of the internal part of the stem bark presents itself in a flat shape, with smooth texture and a pale yellow color. The phloem is composed by axial parenchyma cells and radial parenchyma cells, sometimes more elongated than the axial cells, sieve tube elements, companion cells and angle fibers. Through histochemical testing, the presence of alkaloids, starch grains, calcium oxalate crystals and lipid drops was detected. The species should be include in further phytochemical and pharmacological studies, since is widely used in Brazilian traditional medicine.

\section{REFERENCES}

ALICE, C.B. et al. Screening of plants used in South Brazilian folk medicine. Journal of Ethnopharmacology, v. 35, p. 165-171, 1991.

ARGÜESO, A.D.A. Manual de tecnicas en histologia vegetal. 1.ed. Buenos Aires, Argentina: Hemisferio Sur, 1986. 83p.

AZMIR, J. et al. Techniques for extraction of bioactive compounds from plant materials: A Review. Journal of Food Engineering, v. 117, p. 426-436, 2013.

BARROS, F.M.C. et al. Plantas de uso medicinal no município de São Luiz Gonzaga. Latin American Journal of Pharmacy, v. 26, n. 5, p. 652-662, 2007.

BARSETT, $H$. et al. Comparison of carbohydrate structures and immunomodulating properties of extracts from berries and flowers of Sambucus nigra L. European Journal of Medicinal Plants, v. 2, n.3, p. 216-229, 2012.

CARVALHO, J.L.S. et al. Termoestabilidade de processos extrativos de Nasturtium officinale R. Br., brassicaceae por sistema Soxhlet modificado. Quimica Nova, v. 32, p. 1031-1035, 2009.

CHUA, L.S. A review on plant-based rutin extraction methods and its pharmacological activities. Journal of Ethnopharmacology, v. 150, p. 805-817, 2013.

CORADIN, L. et al. Espécies nativas da flora brasileira de valor econômico atual ou potencial: plantas para o futuro - Região Sul. 2.ed. Brasília, Brasil: MMA, 2011. 934p.

DAI, J. \& MUMPER, R.J. Plant Phenolics: Extraction, analysis and their antioxidant and anticancer properties. Molecules, v. 15, p. 7313-7352, 2010.

EBRAHIMZADEH, M.A. et al. Anti-inflammatory activity of Sambucus ebulus hexane extracts. Fitoterapia, v. 77, p. 146-148, 2006.

Farmacopéia Brasileira. 1996. 4ed, Atheneu, São Paulo, Brasil.

Farmacopéia Brasileira. 2000. 4ed, Atheneu, São Paulo, Brasil.

Farmacopéia Brasileira. 2010. 5ed, Fiocruz, Brasília, Brasil.

FAZIO, A. et al. Comparative analysis of seeds of wild fruits of Rubus and Sambucus species from Southern Italy: Fatty acid composition of the oil, total phenolic content, antioxidant and anti-inflammatory properties of the methanolic extracts. Food Chemistry, v. 140, n.4, p. 817-824, 2013.

HAMISSA, A.M.B. et al. Phenolics extraction from Agave americana (L.) leaves using high-temperature, highpressure reactor. Food and Bioproducts Processing, v. 90, p. 17-21, 2012.

JUDD, W.S. et al. Sistemática Vegetal: um enfoque filogenético. 3. ed. Porto Alegre, Brasil: Artmed, 2009. $612 p$.

LAPORNIK, B. et al. Comparison of extracts prepared from plant by-products using different solvents and extraction time. Journal of Food Engineering, v. 71, p. 214-222, 2005.

LEITE, J.P.V. Fitoterapia: bases científicas e tecnológicas. 1.ed. São Paulo, Brasil: Atheneu, 2009. $328 p$.

LUQUE DE CASTRO, M.D; PRIEGO-CAPOTE, F. Soxhlet extraction: Past and present panacea. Journal of Chromatography A, v. 1217, p. 2383-2389, 2010.

MACÊDO, N.A. Manual de técnicas em histologia vegetal. 1.ed. Feira de Santana, Rio de Janeiro, Brasil: UEFS, 1997. 96p.

METCALFE, C.R.; CHALK, L. Anatomy of the dicotyledons: Systematic anatomy of leaf and stem, with a brief history of the subject. 2.ed. Estados Unidos da América: Clarendon Press, 1979. 304p.

NEWMAN, D.J. \& CRAGG, G.M. Natural products as sources of new drugs over the 30 years from 1981 to 2010. Journal of Natural Products, v. 75 , p. 311-335, 2012.

NUNES, E. et al. Caracterização farmacobotânica das espécies de Sambucus (Caprifoliaceae) utilizadas como medicinais no Brasil. Parte II. Sambucus australis Cham. \& Schltdl. Revista Brasileira de Farmacognosia, v. 17, n. 3, p. 414-425, 2007.

OZGEN, M. et al. Total phenolic, anthocyanin contents and antioxidant capacity of selected elderberry (Sambucus canadensis L.) accessions. Pharmacognosy Magazine, v. 6, p. 198-203, 2010.

PÉRES, V.F. et al. Comparison of soxhlet, ultrasoundassisted and pressurized liquid extraction of terpenes, fatty acids and Vitamin E from Pipergaudichoudianum Kunth. Journal of Chromatography A, v. 1105, p. 115-118, 2006.

RAMBO, D.F. et al. Morphoanatomical identification and physicochemical parameters of the drug Erythrina verna Vell. trunk bark. Boletín Latinoamericano y del Caribe de Plantas Medicinales y Aromáticas, v. 12 , n. 3, p. $243-256,2013$.

RAO, V.S. et al. Ursolic acid, a pentacyclic triterpene from Sambucus australis, prevents abdominal adiposity in mice fed a high-fat diet. Journal of Medicinal Food, v. 14, p. 1375-1382, 2011.

RATZ- $Ł Y K O, A$. et al. The influence of polyphenols on the physiological processes in the skin. Phytotherapy Research, v. 29, p. 509-517, 2015.

SCALIA, S. et al. Anatytical and preparitive supercritical fluid extraction of Chamomile flowers and its comparison with convetional methods. Journal of Pharmaceutical and Biomedical Analysis, v. 21, p. 549-558, 1999.

SCOPEL, M. et al. 2010. Comparative analysis of Sambucus nigra and Sambucus australis flowers: development and validation of an HPLC method for raw

Rev. Bras. PI. Med., Campinas, v.18, n.1, supl. I, p.223-229, 2016. 
material quantification and preliminary stability study. Planta Medica, v. 76, n.10, p. 1026-1031, 2010.

SEN, C.K. et al. Human skin wounds: A major and snowballing threat to public health and the economy. Wound Repair and Regeneration, v.17, n. 6, p. 763$771,2009$.

$\mathrm{SHI}, \mathrm{J}$. et al. Extraction of polyphenolics from plant materials for functional foods - Engineering and technology. Food Reviews International, v. 21, p. 139-166, 2005.

SOBRAL, M. Adoxaceae. In: FORZZA, RC., org., et al. Catálogo de Plantas e Fungos do Brasil. [online]. Rio de Janeiro: Andrea Jakobsson. Estúdio: Instituto de Pesquisa Jardim Botânico do Rio de Janeiro, 2010. p.585. Vol. 1.

SOMAVILLA, N.; CANTO-DOROW, T.S. Levantamento das plantas medicinais utilizadas em bairros de Santa Maria, RS. Ciências e Natura, v. 18, p. 131-148, 1996.

SÜNTAR, I.P. et al. Wound healing potential of Sambucus ebulus L. leaves and isolation of an active component, quercetin 3-O-glucoside. Journal of Ethnopharmacology, v. 129, p. 106-114, 2010.

VENDRUSCOLO, G.S. Estudo etnobotânico das plantas utilizadas como medicinais por moradores do brairro Ponta Grossa, Porto Alegre, Rio Grande do Sul. 2004. 227p. (Tese de Doutorado - Área de Concentração em Botânica). Departamento de Botânica, Universidade Federal do Rio Grande do Sul, Porto Alegre.

ZHANG, T. et al. Simultaneous analysis of seven bioactive compounds in Sambucus chinensis Lindl. by HPLC. Analytical Letters, v. 43, p. 2525-2533, 2010. 